\title{
Methemoglobin binding to model phospholipid membranes
}

\author{
G. P. Gorbenko
}

Kharkov State University

4 Svobody Sq., Kharkiv, 61077, Ukraine

\begin{abstract}
The interaction of methemoglobin with model phospholipid membranes compased of phosphatidylcholine and its mixtures with phosphatidylserine or diphosphatidylglycerol has been studied. The binding isotherms have been analyzed in terms of two-dimensional lattice models of surface adsorption and incorporation of the protein into the lipid bilayer. The binding parameters including an association constant, binding stoichiometry, enthalpy and entropy contributions to free energy change have been estimated.
\end{abstract}

Introduction. Model protein-lipid systems are presently widely used to gain insight into the nature of interactions between two major membrane constituents - proteins and lipids [1, 2]. Protein component of these systems is often represented by nonmembraneous water soluble proteins, being capable of forming complexes with lipids $[3,4]$. One of the proteins employed in such model studies is hemoglobin [5].

Numerous data available in the literature are indicative of the possibility of hemoglobin binding to lipid bilayer by means of electrostatic and hydrophobic interactions $[5-7]$. To date, hemoglobin structure is well characterized, thus providing a basis for elucidation of general principles and driving forces of protein-lipid interactions. One important aspect of the problem envisaged concerns the factors governing the thermodynamics of the protein association with a lipid bilayer.

The main goal of the present work was to examine thermodynamic characteristics of methemoglobin (metHb) complexes with phospholipids. Analysis of the binding isotherms in terms of two-dimensional lattice models of large ligand adsorption to membranes allowed to estimate association constant, stoichiometry of binding, enthalpy and entropy contributions to the free energy change. As a lipid component of the model systems studied liposomes composed of phosphatidylcholine (PC) and its mixtu-

C) G. P. GORBENKO, 2000 res with phosphatidylserine (PS) and diphosphatidylglycerol (DPG) were employed.

Materials and Methods. Egg yolk PC, beef heart DPG and beef brain PS were purchased from Bakpreparat (Kharkiv, Ukraine). Oxyhemoglobin was isolatied from human blood according to [8] and converted to metHb by adding of potassium ferricyanide with subsequent gel-filtration on molselect G-25. Liposomes from $P C$ and its mixtures with PS (3:1, mol:mol) and DPG (6:1, mol:mol) were obtained as follows. Ethanol lipid's solution was evaporated under vacuo and lipid film was then suspended in 10 mM T'ris-HCl buffer, pH 7.4, to a final lipid concentration of $10 \mathrm{mg} / \mathrm{ml}$. Lipid suspension was shaked for $10 \mathrm{~min}$, sonicated for $3 \mathrm{~min}, 4^{\circ} \mathrm{C}$ and centrifuged at $30000 \mathrm{~g}$ for $30 \mathrm{~min}$ in order to remove multilamellar vesicles. Liposomes with average diameter of ca. 100 nm, remaining in supernatant, were used in experiments. Phospholipid concentration was determined according to [9]. Protein concentration was found using extinction coefficient $E_{407}=5.66 \cdot 10^{5} \mathrm{M}^{-1} \mathrm{~cm}^{-1}$ [10].

Results and Discussion. In analyzing the protein (P) association with lipids (L) one of the following approaches is commonly used. Within the framework of traditional approach lipid bilayer is treated as consisting of discrete protein's binding sites, each containing $n$ lipid molecules. In this case binding curves are described by Langmuir isotherm, being applied to a simple chemical equilibrium: $\mathrm{P}+n \mathrm{~L} \leftrightarrow$ $\leftrightarrow \mathrm{P} \cdot n \mathrm{~L}$. However, as indicated in a number of 
studies $[11-14]$, this approach appears to be inadequate in examining protein-lipid interactions for the following reasons. First of all, the protein must be considered as large ligand, interacting with an array of binding contacts on a membrane surface and covering simultaneously $n$ lipid molecules. Additionally, adsorption of large ligand on the surface can lead to the steric constraints depending on the spatial arrangement of the lipids in the protein-lipid contact region,

Such peculiarities of the protein interaction with lipid bilayer have been taken into account in a series of models, particularly, in the models proposed by Stankowski [12, 13]. It seems also noteworthy that there exists an approach, principally differing from those mentioned above. It based on the consideration of the protein association with an assembly of lipids, rather than with individual molecules comprising lipid bilayer, so that protein-lipid interactions are interpreted as partitioning of the protein between aqueous and membrane phases, characterizing only by partition coefficient [14].

In the present paper two-dimensional lattice models of Stankowski $[12,13]$ have been used to analyze quantitatively metHb binding to liposomes of various composition. Lipid bilayer was modeled as hexagonal lattice with structural subunits represented by lipid molecules. According to the formalism employed, two limiting cases, corresponding to the linear and discoid ligand shape, were considered. Note that the concept of «ligand shape» means geometrical arrangement of binding contacts in the protein-lipid complex. Adsorption of linear ligand on the membrane surface was described by $[13]$ :

$$
\begin{gathered}
K_{u} F=\frac{r}{1-n r}\left(\frac{1-(1-\lambda) n r}{1-n r}\right)^{n-1} ; \\
r=\frac{B}{L} ; \lambda=\frac{z-2}{z}-\frac{2}{n z},
\end{gathered}
$$

where $B, F$ are the concentrations of bound and free protein, respectively, $L$ is the total lipid concentration, $n$ is the number of lipid molecules per molecule of bound protein, $K_{\alpha}$ is association constant, $z$ is the lattice coordination number $(z=6)$. Assuming that ligand has a shape of disc the following relationship was used:

$$
K_{a} F=\frac{r}{1-n r} \exp \left(\frac{a n r}{1-\omega r}\right),
$$

where $\alpha$ is the parameter of excluded area $(\alpha=3)$, $\omega=2 \sqrt{3 n} / \vec{\pi}$.

Equations (1) $\rightarrow(3)$ were used to analyze experimental data obtained for negatively charged liposomes, composed of PC mixtures with PS or DPG

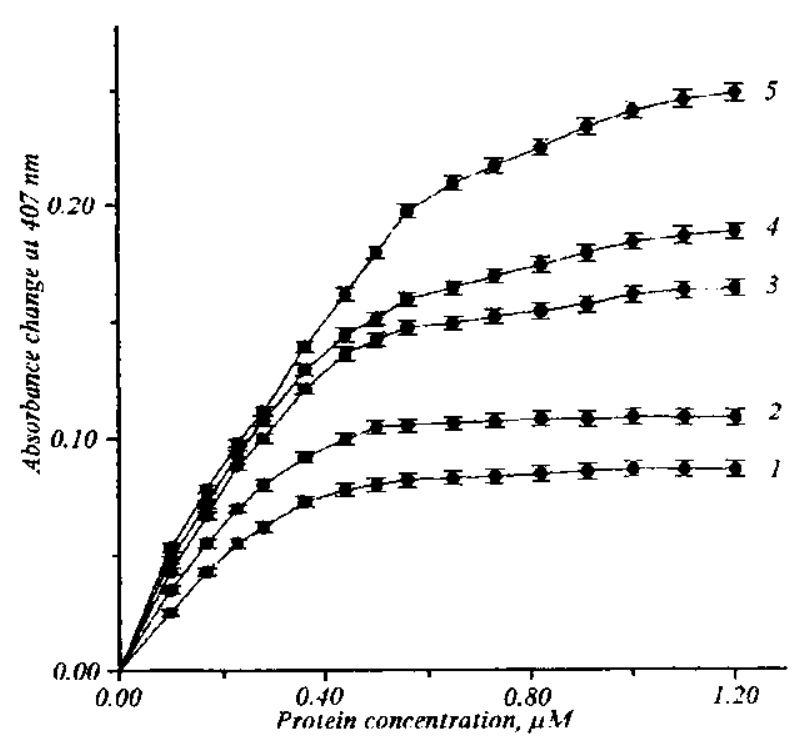

Fig. 1. The isotherms of methemoglobin binding to liposomes composed of phosphatidylcholine and phosphatidylserine $(3: 1$, mol:mol). Temperature, ${ }^{\circ} \mathrm{C}: 1-4 ; 2-13 ; 3-24 ; 4-31 ; 5-$ 37. Lipid concentration $0.8 \mathrm{mM}$

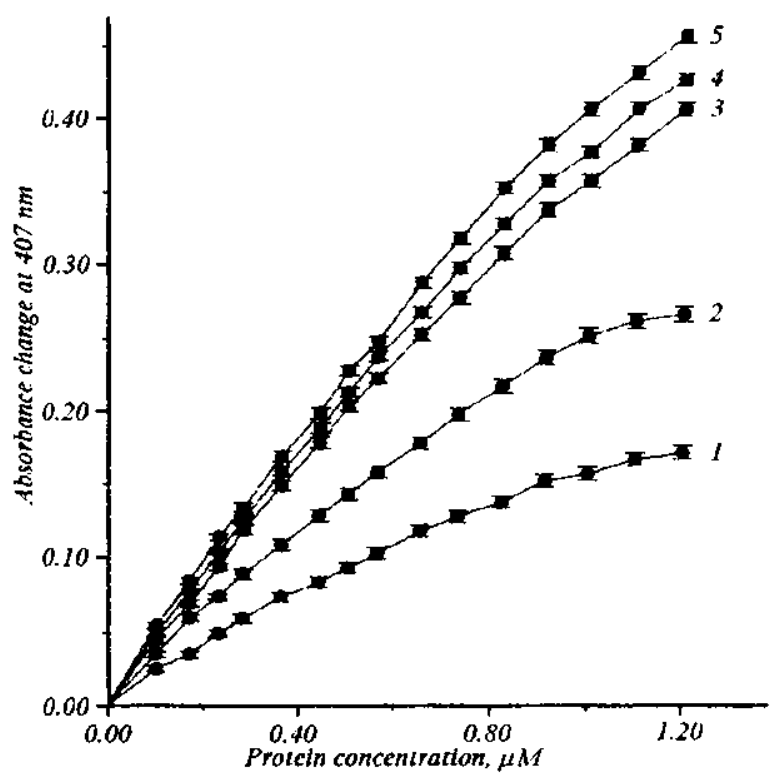

Fig. 2. The isotherms of methemoglobin binding to liposomes composed of phosphatidylcholine and diphosphatidylglycerol (6:1, mol:mol). Temperature, ${ }^{\circ} \mathrm{C}: 1-4 ; 2-13 ; 3-24 ; 4-31 ; 5-$ 37. Lipid concentration $0.8 \mathrm{mM}$ 
(Fig. 1, 2). In this case it was assumed that the main type of protein-lipid interactions is the adsorption of the protein molecule on membrane surface due to formation of electrostatic contacts. Meanwhile, taking into account the findings provided by a number of studies $[6,7,15]$, preferential mode of metHb interaction with neutral $\mathrm{PC}$ vesicles was supposed to be the protein penetration into bilayer interior. Therefore the binding curves observed for PC liposomes (Fig. 3) were treated in terms of the model of protein incorporation in the membrane [13]:

$$
K_{\alpha} F=\frac{r}{1+n r}\left(\frac{1+n r}{1+\lambda n r}\right)^{\gamma \hat{i} /(1-\lambda)} ;
$$

where for linear ligand:

$$
\lambda=\frac{(z-2)}{z}-\frac{2}{n z} ; \alpha=(n-1) \gamma ; \gamma=\frac{\alpha}{\lambda}
$$

and for disc-like ligand:

$$
\lambda=\frac{2 k+1}{n} ; k=\frac{-1+\sqrt{1+12 n}}{6} .
$$

Parameter $n$ in eqn. (4) corresponds to the number of lipid molecules occupying surface area being equivalent to cross-section of the protein part penetrating in the bilayer.

The binding of metHb to liposomes was examined by monitoring the decrease of protein absor-



Fig. 3. The isotherms of methemoglobin binding to liposomes composed of phosphatidylcholine Temperature, ${ }^{\circ} \mathrm{C}: I-4 ; 2-13$; $3-24 ; 4-31 ; 5-37$. Lipid concentration $0.5 \mathrm{mM}$ bance in Soret band (at wavelength $407 \mathrm{~nm}$ ). This absorbance change is supposed to be a consequence of metHb structural alterations caused by its interaction with lipid's hydroperoxides [16] or negatively charged phospholipids $[17,18]$. According to approach, developed in the previous studies $[20,21]$, it was assunied that absorbance decrease $\left(\Delta A_{407}\right)$ is proporticinal to the concentration of the bound protein (B):

$$
\Delta \boldsymbol{A}_{\mathbf{4 0 7}}=a \mathrm{~B} \text {, }
$$

where $a$ is coefficient of proportionality. The measured value of $\left(\Delta A_{407}\right)\left(\Delta A_{r}\right)$ was corrected for the light scattering of the protein-lipid mixture using the following relationship [20]:

$$
\Delta A_{407}=\Delta A_{r}-\left(\frac{\lambda_{0}}{\lambda}\right)^{m} \Delta A\left(\lambda_{0}\right),
$$

where $\lambda_{0}$ is the wavelength from the region of negligibly small protein absorbance $\left(\lambda_{0}=700 \mathrm{~nm}\right)$, $\lambda=407 \mathrm{~nm}$. Parameter $m$, determined by the sample turbidity, was estimated from the plots $\lg A v s . \lg \lambda$ obtained at wavelengths $600-700 \mathrm{~nm}$, according to equation:

$$
m=\frac{\Delta \lg A}{\Delta \lg \lambda}
$$

The $\alpha$ estimate, used subsequently as one of the paranteters in the data fitting, was obtained as described in detail elsewhere [21], by extrapolating the results of the protein titration by liposomes to infinite lipid concentration. Given that $B=\Delta A_{407} / a$ and using eqns (1)-(6) for determination of $F$, one can calculate the value of the total protein concentration $\left(P_{0}=B+F\right)$ for a certain set of parameters $a$, $n$ and $K_{a}$. The value of $n$ and $K_{a}$ giving the best fit of experimental data were found by minimizing a function:

$$
f=\frac{1}{m} \sum_{i=1}^{m}\left(P_{0}^{e}-P_{0}^{c}\right)^{2},
$$

where $\boldsymbol{P}_{0}{ }^{c}$ and $\boldsymbol{P}_{0}{ }^{e}$ are calculated and determined experimentally concentrations of the protein, $m$ is the number of experimental points.

F'resented in Table 1 are the parameters $n$ and $K_{a}$ characterizing metHb association with liposomes of various composition. Since the ligand shape is unknown and proves to be irregular, the lower and upper limits of $n$ were assessed assuming linear or discoid ligand shape, respectively. Because the crosssection of metHb molecule being ca. $2600 \AA$, corresponds: to the area of ca. 37 lipid molecules, it seems likely that real shape of contact region in the protein- 
Table I

Parameters of methemoglobin binding to liposomes derived from the fitting of experimental data to eqns. (I)-(6)

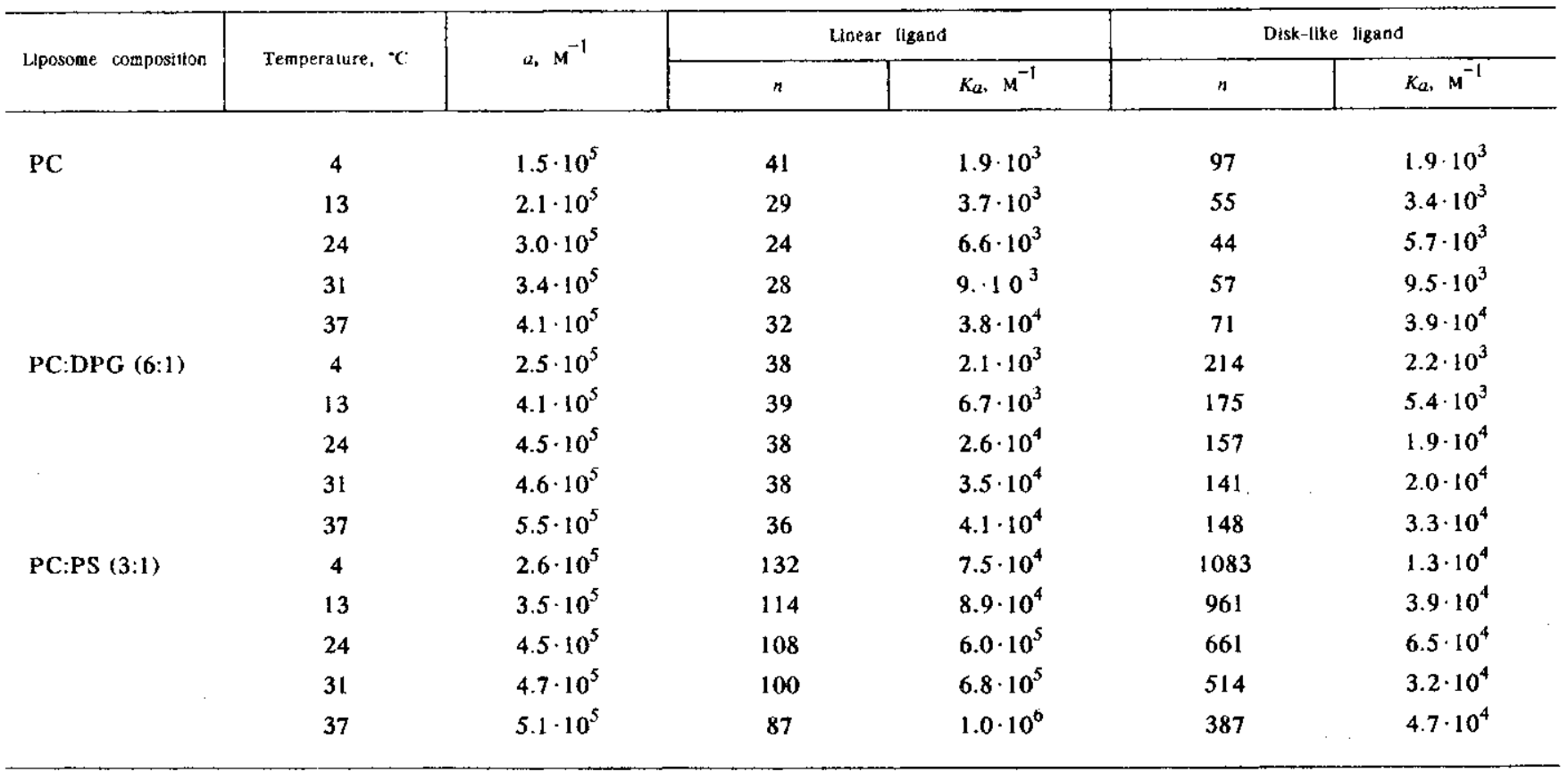

The error of parameter estimation does not exceed $17 \%$ for $K_{\alpha} 20 \%$ for $n$ and $12 \%$ for $a$

lipid complexes is closer to linear. It should be emphasized that parameter $n$ accounts for a total amount of lipid molecules that are excluded from the further ligand binding upon the adsorption of one protein molecule. The actual number of protein-lipid contacts in some cases can be less than $n$. Such a situation may take place, for instance, when the protein binds preferentially to the charged lipid headgroups, that form clusters upon the protein association with lipid bilayer [13]. Taking into account this possibility, relatively high $n$ values, derived for liposomes PC:PS (Table 1) can be interpreted in terms of preferential metHb binding to negatively charged PS molecules. In this case the number of lipids in contact with the protein $\left(n^{*}\right)$ can be evaluated as $n f$, where $f$ is the fraction of charged lipid $(f=0.25)$. The values of $n^{*}$, obtained in such a way, would be closer to aforementioned estimates, based on the protein cross-section and the area of lipid's headgroup.

The value of association constant (Table 1) observed at different temperatures were further used to estimate free energy change $(\Delta G)$ and its enthalpy $(\Delta H)$ and entropy $(\Delta S)$ contributions:

$$
\Delta G=-R T \ln K_{a}=\Delta H-T \Delta S .
$$

Rearranging eqn. (11), one obtains:

$$
\ln K_{\alpha}=\frac{\Delta S}{R}-\frac{\Delta H}{R T} .
$$

The fitting of $\ln K_{a}$ plots $v s$. 1/T to eqn. (12) allowed to evaluate $\Delta H$ and $\Delta S$. As can be seen from Table 2, the formation of metHb complexes with liposomes is characterized by positive enthalpy and entropy changes. The values of $\Delta G$ are consistent with those reported elsewhere for model peptides [19] and proteins [22]. According to the modern theories of protein-lipid interactions there exist at least five factors controlling the thermodynamics of the protein binding to lipid bilayer, namely i) formation of electrostatic contacts, ii) hydrophobic effect and alterations in iii) the network of hydrogen bonds, iv) protein entropy and v) lipid ordering [23]. As follows from the theoretical predictions, changes in hydrogen 
Table 2

Thermodynamic parameters of methemoglobin interaction with liposomes

\begin{tabular}{|c|c|c|c|c|c|c|}
\hline \multirow{2}{*}{ Liposome composition } & \multicolumn{3}{|c|}{ Leear tizand } & \multicolumn{3}{|c|}{ Disc-like ligand } \\
\hline & $\Delta G$, kcal $M^{-1}\left(244^{\circ} \mathrm{C}\right)$ & $\Delta H$, kcal $\mathrm{M}^{-1}$ & $\Delta s$, cal $\mathrm{M}^{-1} \mathrm{~K}^{-1}$ & $\Delta G$, kcal $\mathrm{M}^{-1}\left(24^{\circ} \mathrm{C}\right)$ & $\Delta H$, kcat $\mathrm{M}^{-1}$ & As, cal $\mathrm{M}^{-1} \mathrm{~K}^{-1}$ \\
\hline PC & -5.2 & 13.5 & 63.7 & -5.1 & 13.7 & 64.3 \\
\hline PC:DPG (6:1) & -6.0 & 15.8 & 73.1 & -5.8 & 14.0 & 66.3 \\
\hline PC:PS (3:1) & -7.8 & 15.0 & 76.4 & -6.5 & 13.3 & 67.4 \\
\hline
\end{tabular}

bonding and lipid ordering do not contribute noticeably to the total $\Delta G$ value. However, another factors afore-mentioned may be of significance. The results presented here suggest that the main driving force of metHb interaction with lipids is energetically favourable entropy increase. This, in turn, can be caused by i) formation of ionic contacts in water, ii) transfer of nonpolar amino acid sidechains in the membrane interior and iii) unfolding of the protein molecule [23]. In this context it seems important to note that negatively charged lipids, including PS and DPG, can exert destabilizing influence on metHb structure $[17,18]$.

Taken together, the results of the present study indicate that two-dimensional lattice models allow to obtain reasonable estimates of the binding parameters, characterizing either surface adsorption or protein incorporation in the lipid bilayer. From thermodynamical viewpoint, entropy factor was found to play determining role in metHb association with the model phospholipid membranes.

Acknowledgements. I thank the referee for the valuable remarks.

\section{Г. Л. Горбенко}

Зв'язування метгемоглобіну 3 модельними фосфолілідними мембранами

Резюме

Дослідхували взасмодію метzемоглобіну $з$ модельними фосфоліпідними мембранами, сформованими з фосфатидилхоліну та його сумішей з фосфатидилсерином $і$ діфосфатидилглічерином. Ізотерми зө'язуеання проаналізовано в рамках дөовимірних моделей адсорбиї на поверхні та проникнения білка в ліпідний бінар. Здійснено ощінку константи асоиіацї, стехіометріи зв"язування, өнесків ентальпійного та ентропійноzо факторів у змінення віньної енергї̈ при утворенні білоклinidних комплексів.

\section{Г. П. Горбенко}

СвязыЕание метемоглобина с модельными фосфолипидными мембранами

Резюм:

Исследоєали взаимодействие метгемоглобина с модельньми фосфомипидными мембранами, состояними из фосфатидилхо лина и его смесей с фосфатидилсерином и дифосфатидилглице рином. Изотермы связывания проанализированы в рамках двухмерных решеточных моделей адсорбиии на поверхности и встраивания белка в липидный бислой. Проведена оценка кон станты ассоциации, стехиометрии связывания, вкладов энmольпийного и энтропийного факторов в изменение свободной энергии при образовании белок-липидньх комплексов.

\section{REFERENCES}

1. Kimelberg $H . K$. Protein-liposome interactions and their rele vance to the structure and function of cell membranes $/ / \mathrm{Mol}$. and Cell. Biochem. $-1976 .-10$, N 3.-P. $171-190$.

2. $T$ amm $L$ Membrane insertion and lateral mobility of synthetic ataphiphilic signal peptides in lipid model membranes // Biochim. et biophys. acta.-1991.-1071.-P. 123-148.

3. Heimburg $T$., Marsh $D$. Protein surface distribution and protein-protein interactions in the binding of peripheral proteins to charged lipid membranes // Biophys. J.-1995.68. -P. 5436-5546.

4. Marsh $D$. Stoichiometry of lipid-protein interaction and integral membrane protein structure // Eur. Biophys. J.—1997.-26. P. 203-208.

5. Ушакова И. П., Васитенко И. А., Серебренникова I: А., Eзстигнеева $P$. $\Pi$. Изучение взаимодействия метгемоглобина с фосфолипидными бислойными мембранами метсдом флюоресценции // Биоорг. химия.-1981.-7 Nos 4.-C. $613-620$.

6. С.лезнев С. А., Громов Н. Г. Образование гемоглобинмитиных комплексов как модель взаимодейстиия основнах компонентов клеточных мембран // Биофизиха.$1483 .-28$, № 3. - C. 521 .

7. Горбенко Г. П., Древаль В. И. Взаимодействие метгемоглобина с фосфолигидными везикулами // Бмополимеры и клетка.-1990.-6, № 2.-С. 87-90.

8. Ризенберг Г. Я. Вязова Е. П., Иванова Г. Н., Уиакова М. М., Иванов К. Г., Рутберг Р. А. Получение очищенного 
препарата гемоглобина и изучение его свойств // Проблемы гематологии и переливания крови.-1975.-20, № 11 - - C. $25-29$.

9. Кейтс М. Техника липидологии.-М.: Мир, 1975.-322 с.

10. Benesch R., Benesch E., Yung S. Equations for the spectrophotometric analysis of hemoglobin mixtures // Anal. Biochem. $-1973 .-55 . \rightarrow$ P. $245-248$.

11. Chatelier $R$. C., Minton A. P. Adsorption of globular proteins on locally planar surfaces: models for the effect of excluded surface area and aggregation of adsorbed protein on adsorption equilibria // Biophys. J.-1996.-71.-P. 2367-2374.

12. Stankowski $S$. Disc-like ligands and shape dependence at low saturation // Biochim. et biophys. acta. $-1983 .-735, \mathrm{~N} 3 .-$ P. $352-360$.

13. Stankowski $S$. Large ligand adsorption to membranes. Cooperativity and general ligand shapes // Biochim. et biophys. acta. - 1984.-777, N 2.-P. 167-182.

14. White S. H., Wimley W. C., Ladokhin A. S., Hristova $K$. Protein folding in membranes: determining energetics of peptide-bilayer interactions // Meth. Enzymol.-1998.-295.P. $62-87$.

15. Bassi L., Alema S., Calissano P., Marra E. Interaction of different forms of hemoglobin with artificial lipid membranes // Biochim. et biophys. acta. $-1975 .-375, N$ 3.-P. 477-482.

16. Горбенко $\Gamma$. П. Индуцируемое метгемоглобином перекисное окисление липидов в модельных мембранах // Укр. биохим. журн. -1992.-64, № 4.-C. 108-112.
17. Marva E., Hubbel $R$. Denaturing interaction between sickle hemoglobin and phosphatidylserine liposomes // Blood.1994.-83, N 1.-P. 242-249.

18. Shviro Y., Zilber 1 , Shaklai $N$. The interaction of hemoglobin with phosphatidylserine vesicles // Biochim. et biophys. acta. $-1982 .-687 .-$ P. $63-70$.

19. Ladokhin A. S., Selsted $M$. E., White S. H. Bilayer interactions of indolicidin, a small antimicrobial peptide rich in tryptophan, proline and basic amino acids // Biophys. 3.1997.-72.-P. 794-805.

20. Горбенко $Г$. П., Дрєваль В. И. Изучение взаимодействия феррицитохрома С с липосомами // Укр. биохим. журн.1990.-62, № 5.-P. 106-111.

21. Gorbenko $G$. P. Resonance energy transfer study of hemoglobin and cytochrome $C$ complexes with lipids $/ /$ Biochim. et biophys. acta.-1998.-1409.-P. $12-24$.

22. Heymann J. B., Zakharov S. D., Zhang Y. L., Cramer W. A Characterization of electrostatic and nonelectrostatic components of protein-membrane binding interactions // Biochemistry. -1996. -35.-P. 2717--2725.

23. Abney Y., Owicki Y. Theories of protein-lipid and proteinprotein interactions in membranes // Progr. Prot.-Lipid Interact.-Amsterdam, 1986.-P. $1-60$.

УДК 577.37

Received 21.07.98 